\title{
Different Roles of 12/15-Lipoxygenase in Diabetic Large and Small Fiber Peripheral and Autonomic Neuropathies
}

\author{
Irina G. Obrosova, ${ }^{*}$ Roman Stavniichuk, ${ }^{*}$ \\ Viktor R. Drel, ${ }^{*}$ Hanna Shevalye, ${ }^{*}$ Igor Vareniuk, ${ }^{*}$ \\ Jerry L. Nadler, ${ }^{\dagger}$ and Robert. E. Schmidt ${ }^{\ddagger}$ \\ From the Pennington Biomedical Research Center," Louisiana \\ State University System, Baton Rouge, Louisiana; the Department \\ of Internal Medicine, ${ }^{\dagger}$ Eastern Virginia Medical School, Norfolk, \\ Virginia; and the Department of Pathology and Immunology, ${ }^{\ddagger}$ \\ Washington University School of Medicine, St. Louis, Missouri
}

Up-regulation of 12/15-lipoxygenase, which converts arachidonic acid to 12(S)- and 15(S)-hydroxyeicosatetraenoic acids, causes impaired cell signaling, oxidative-nitrosative stress, and inflammation. This study evaluated the role for 12/15-lipoxygenase in diabetic large and small fiber peripheral and autonomic neuropathies. Control and streptozotocin-diabetic wildtype and 12/15-lipoxygenase-deficient mice were maintained for 14 to 16 weeks. 12/15-lipoxygenase gene deficiency did not affect weight gain or blood glucose concentrations. Diabetic wild-type mice displayed increased sciatic nerve 12/15-lipoxygenase and 12(S)hydroxyeicosatetraenoic acid levels. 12/15-lipoxygenase deficiency prevented or alleviated diabetesinduced thermal hypoalgesia, tactile allodynia, motor and sensory nerve conduction velocity deficits, and reduction in tibial nerve myelinated fiber diameter, but not intraepidermal nerve fiber loss. The frequencies of superior mesenteric-celiac ganglion neuritic dystrophy, the hallmark of diabetic autonomic neuropathy in mouse prevertebral sympathetic ganglia, were increased 14.8-fold and 17.2-fold in diabetic wild-type and 12/15-lipoxygenase-deficient mice, respectively. In addition, both diabetic groups displayed small $(<1 \%)$ numbers of degenerating sympathetic neurons. In conclusion, whereas 12/15-lipoxygenase up-regulation provides an important contribution to functional changes characteristic for both large and small fiber peripheral diabetic neuropathies and axonal atrophy of large myelinated fibers, its role in small sensory nerve fiber degeneration and neuritic dystrophy and neuronal degeneration characteris- tic for diabetic autonomic neuropathy is minor. This should be considered in the selection of endpoints for future clinical trials of 12/15-lipoxygenase inhibitors. (Am J Pathol 2010, 177:1436-1447; DOI: 10.2353/ajpath.2010.100178)

Diabetic distal symmetric sensorimotor polyneuropathy affects at least $50 \%$ of subjects with both Type 1 and Type 2 diabetes mellitus in the United States, ${ }^{1,2}$ and is a leading cause of foot amputation. Clinical manifestations of peripheral diabetic neuropathy (PDN) include increased vibration and thermal perception thresholds that progress to sensory loss developing at least partially because of degeneration of all types of fibers in the somatic nerve. A significant proportion of patients with PDN experience abnormal sensations such as paresthesias, allodynia, hyperalgesia, and spontaneous pain. Diabetic autonomic neuropathy (DAN) ranging in severity from minor papillary and sweating problems to significant disturbances in cardiovascular, alimentary, and genitourinary functions, results in significantly increased patient morbidity and mortality. ${ }^{3}$ Improved blood glucose control reduces the risk of PDN and DAN in both Type $1^{4}$ and Type $2^{5}$ diabetes, thereby strongly implicating hyperglycemia as a causative factor.

Numerous studies in animal models of PDN and DAN identified multiple mechanisms linking hyperglycemia to nerve conduction slowing and small sensory nerve fiber dysfunction. Those include but are not limited to in-

Supported by National Institutes of Health grants DK074517 (I.G.O.) and $\mathrm{NIH}$ DK019645 (R.E.S.), the American Diabetes Association Research grant 7-08-RA-102 (I.G.O.), and Juvenile Diabetes Research Foundation grant 1-2005-1085 (R.E.S.). The Cell Biology and Bioimaging Core utilized in this work is supported in part by COBRE (NIH P20 RR021945) and CNRU (NIH 1P30-DK072476) center grants from the National Institutes of Health.

Accepted for publication May 24, 2010.

None of the authors disclosed any relevant financial relationships.

Address reprint requests to Irina G. Obrosova, Ph.D., Pennington Biomedical Research Center, Louisiana State University, 6400 Perkins Road, Baton Rouge, LA 70808. E-mail: obrosoig@pbrc.edu. 
creased aldose reductase activity, ${ }^{6-8}$ nonenzymatic glycation/glycooxidation ${ }^{9,10}$ and interactions of advanced glycation end products with their receptors, ${ }^{11,12}$ activation of protein kinase $\mathrm{C}^{13,14}$ and mitogen-activated protein kinases, ${ }^{15}$ oxidative-nitrosative stress, ${ }^{16-18}$ and poly(ADP-ribosyl)ation. ${ }^{19,20}$ Most of the afore-mentioned mechanisms participate in both nerve conduction deficits and small sensory nerve fiber dysfunction characteristic for PDN (reviewed in 21) and functional abnormalities associated with DAN. ${ }^{22-24}$ Note, however, that relatively small number of studies address involvement of hyperglycemia or other factors in the diabetic milieu in structural changes in the peripheral ${ }^{25-34}$ and autonomic nervous systems. ${ }^{35-37}$

Diabetes is associated with disturbances of arachidonic acid metabolism manifest, among other changes, by a depletion of glycerophospholipid arachidonoyl-containing molecular species in peripheral nerve. ${ }^{38}$ One of the enzymes of arachidonic acid metabolism, cyclooxygenase-2, has been reported to contribute to diabetesinduced neurovascular dysfunction, nerve conduction slowing, functional changes characteristic for cardiac autonomic neuropathy, as well as intraepidermal nerve fiber loss and diabetic neuropathic pain. ${ }^{39-42}$ The role for 12/15-lipoxygenase (LO), the enzyme oxidizing esterified arachidonic acid in lipoproteins (cholesteryl esters) and phospholipids with formation of 12(S)- and 15(S)-hydroxyeicosatetraenoic acids [12(S)HETE and 15(S)HETE], has never been explored, although evidence for the important role of this mechanism in diabetic endothelial dysfunction and nephropathy is emerging, ${ }^{43,44}$ and LO has been localized in endothelial and Schwann cells of the peripheral nerve,${ }^{45}$ dorsal root ganglion neurons, ${ }^{46}$ and spinal cord astrocytes ${ }^{47}$ and oligodendrocytes. ${ }^{48}$ The present study evaluated the role for LO in PDN and DAN by comparing severities of peripheral nerve dysfunction, axonal atrophy of large myelinated fibers, intra-epidermal nerve loss, as well as neuritic dystrophic changes in the superior mesenteric (SMG) and celiac ganglia (CG), in diabetic wild-type $\left(\mathrm{LO}^{+/+}\right)$and $\mathrm{LO}$-deficient $\left(\mathrm{LO}^{-/-}\right)$ mice.

\section{Materials and Methods}

\section{Reagents}

Unless otherwise stated, all chemicals were of reagentgrade quality, and were purchased from Sigma Chemical Co., St. Louis, MO. Rabbit polyclonal (clone $\mathrm{H}-100$ ) anti12-lipoxygenase antibody for Western blot analysis was obtained from Santa Cruz Biotechnology, Santa Cruz, CA. For assessment of intra-epidermal nerve fiber density, rabbit polyclonal anti-protein gene product 9.5 (PGP 9.5) antiserum was obtained from UltraClone, Isle of Wight, UK; Alexa Fluor 488 goat anti-rabbit highly crossadsorbed IgG $(\mathrm{H}+\mathrm{L})$ from Invitrogen, Eugene, OR; SuperBlock blocking buffer from Thermo Scientific, Rockford, IL; and the optimum cutting temperature compound from Sakura Finetek USA, Torrance, CA. Vectashield Mounting Medium was obtained from Vector Laborato- ries, Burlingame, CA. Other reagents for immunohistochemistry were purchased from Dako Laboratories, Inc., Santa Barbara, CA.

\section{Animals}

The experiments were performed in accordance with regulations specified by The Guide for the Care and Handling of Laboratory Animals (NIH Publication No. 8523) and Pennington Biomedical Research Center Protocol for Animal Studies. A colony of 12/15-deficient mice $\left(\mathrm{LO}^{-1-}, \mathrm{C} 57 \mathrm{BI} / \mathrm{J} \text { background }\right)^{49,50}$ was established from several breeding pairs provided by Dr. Nadler's laboratory. Mature male C57BI6/J mice were purchased from Jackson Laboratories, Bar Harbor, ME. All of the mice were fed standard mouse chow (PMI Nutrition International, Brentwood, $\mathrm{MO}$ ) and had ad libitum access to water. Male wild-type $\left(\mathrm{LO}^{+/+}\right)$and $\mathrm{LO}^{-/-}$mice were randomly divided into two groups. In one group, diabetes was induced by streptozotocin as we described previously. ${ }^{33,51}$ Nonfasting blood glucose measurements were performed at induction of diabetes and at the end of the study. The mice with blood glucose $\geq 13.8 \mathrm{mmol} / \mathrm{L}$ were considered diabetic. The control and diabetic mice were maintained for 14 weeks. Physiological and behavioral measurements were taken at two time points ie, at the beginning (before induction of diabetes) and at the end of the study, in the following order: tactile response thresholds (first day), thermal response latency (second day), and motor and sensory nerve conduction velocities (MNCV and SNCV, third day). MNCV and SNCV were measured in mice anesthetized with a mixture of ketamine and xylazine (45 $\mathrm{mgkg}^{-1}$ body weight and 15 $\mathrm{mgkg}^{-1}$ body weight, respectively, i.p.). A group of nondiabetic and diabetic wild-type and $\mathrm{LO}^{-1-}$ mice was shipped to Washington University School of Medicine, St. Louis, and, after a 2-week quarantine and acclimatization, were used for assessment of structural characteristic of DAN in Dr. Schmidt's laboratory.

\section{Assessment of PDN}

\section{Anesthesia, Euthanasia, and Tissue Sampling}

The animals were sedated by $\mathrm{CO}_{2}$ and immediately sacrificed by cervical dislocation. Sciatic nerves (a portion above the bifurcation point) were rapidly dissected and frozen in liquid nitrogen for subsequent assessment of LO and 12(S)HETE concentrations. Distal tibial nerves were fixed in $2.5 \%$ glutaraldehyde buffered with 0.05 $\mathrm{mmol} / \mathrm{L}$ sodium cacodylate ( $\mathrm{pH}$ 7.3), for further assessment of myelinated nerve fiber diameter and myelin thickness. Footpads were fixed in ice-cold Zamboni's fixative for further assessment of intraepidermal nerve fiber density.

\section{Physiological and Behavioral Tests}

Sciatic MNCV, hind-limb digital SNCV, thermal algesia (paw withdrawal), and tactile response thresholds we measured as described previously. ${ }^{33,46,51}$ 


\section{IntraEpidermal Nerve Fiber Density}

Footpads were fixed in ice-cold Zamboni's fixative for 3 hours, washed in $100 \mathrm{mmol} / \mathrm{L}$ PBS overnight, and then in PBS containing increasing concentrations of sucrose ie, $10 \%, 15 \%$, and $20 \%, 3$ hours in each solution. After washing, the samples were snap-frozen in OCT compound and stored at $-80^{\circ} \mathrm{C}$. Three longitudinal $50 \mu \mathrm{m}$ thick footpad sections from each mouse were cut on Leica CM1950 cryostat (Leica Microsystems, Nussloch, Germany). Nonspecific binding was blocked by $3 \%$ goat serum containing $0.5 \%$ porcine gelatin and $0.5 \%$ Triton $\mathrm{X}$-100 in SuperBlock blocking buffer at room temperature, for 2 hours. The sections were incubated overnight with PGP 9.5 antiserum in 1:400 dilution, at $4^{\circ} \mathrm{C}$ after which secondary Alexa Fluor $488 \mathrm{lgG}(\mathrm{H}+\mathrm{L})$ in 1:1000 was applied at room temperature, for 1 hour. Sections were then coverslipped with Vectashield mounting medium. Intraepidermal nerve fiber profiles were counted blindly by three independent investigators under Axioplan 2 microscope (Zeiss) at $\times 40$ magnification, and the average values were used. The length of epidermis was assessed on the microphotographs of stained sections taken at $\times 5$ magnification with a 3I Everest imaging system (Intelligent Imaging Innovations, Inc., Denver, CO) equipped with Axioplan 2 microscope (Zeiss), using the NIH ImageJ software (version 1.42q). An average of $2.8 \pm 0.3 \mathrm{~mm}$ of the sample length was investigated to calculate a number of nerve fiber profiles per $\mathrm{mm}$ of epidermis. Representative images of intraepidermal nerve fibers were obtained by confocal laser scanning microscopy at $\times 40$ magnification, using Leica TCS SP5 confocal system (Leica Microsystems, Mannheim, Germany).

\section{Tibial Nerve Morphometry}

Myelinated fiber diameter and myelin thickness of distal tibial nerves were assessed as described. ${ }^{27}$ The samples fixed overnight at $4^{\circ} \mathrm{C}$ as described above were postfixed in $1 \%$ osmium tetroxide and dehydrated through an ascending series of ethanol concentrations. Fixed nerves were embedded in Epon and polymerized. One-micron thick semithin transverse nerve sections were stained with $\rho$-phenylenediamine. For the morphometric analysis, axonal diameter and myelin thickness were measured at a magnification of $\times 1600$ by a computer-assisted image analyzing system (Scion Image for Windows, Scion Corporation, Frederick, MD).

\section{Biochemical Studies}

\section{Western Blot Analysis of LO}

To assess $L O$ protein expression by Western blot analysis, sciatic nerve material ( $20 \mathrm{mg}$ ) was placed on ice in $200 \mu \mathrm{l}$ of radioimmunoprecipitation assay buffer containing $50 \mathrm{mmol} / \mathrm{L}$ Tris- $\mathrm{HCl}, \mathrm{pH} 7.2 ; 150 \mathrm{mmol} / \mathrm{L} \mathrm{NaCl} ; 0.1 \%$ sodium dodecyl sulfate; $1 \%$ NP-40; 5 mmol/L EDTA; 1 $\mathrm{mmol} / \mathrm{L}$ EGTA; $1 \%$ sodium deoxycholate and the protease/phosphatase inhibitors leupeptin $(10 \mu \mathrm{g} / \mathrm{ml})$, pepstatin $(1 \mu \mathrm{g} / \mathrm{ml})$, aprotinin $(20 \mu \mathrm{g} / \mathrm{ml})$, benzamidine (10 $\mathrm{mmol} / \mathrm{L})$, phenylmethylsulfonyl fluoride $(1 \mathrm{mmol} / \mathrm{L})$, and sodium orthovanadate $(1 \mathrm{mmol} / \mathrm{L})$, and homogenized on ice. The homogenates were sonicated $(4 \times 10 \mathrm{~s})$ and centrifuged at $14,000 \times g$ for 20 minutes. All of the afore-mentioned steps were performed at $4^{\circ} \mathrm{C}$. The lysates (20 $\mu \mathrm{g}$ protein) were mixed with equal volumes of $2 \times$ sample-loading buffer containing $62.5 \mathrm{mmol} / \mathrm{L}$ Tris$\mathrm{HCl}, \mathrm{pH} 6.8 ; 2 \%$ SDS; $5 \% \beta$-mercaptoethanol; $10 \%$ glycerol and $0.025 \%$ bromophenol blue, and fractionated in $7.5 \%$ SDS-polyacrylamide gel in an electrophoresis cell (Mini-Protean III; Bio-Rad Laboratories, Richmond, CA). Electrophoresis was conducted at $15 \mathrm{~mA}$ constant current for stacking, and at $25 \mathrm{~mA}$ for protein separation. Gel contents were electrotransferred ( $80 \mathrm{~V}, 2$ hours) to nitrocellulose membranes using Mini Trans-Blot cell (Bio-Rad Laboratories, Richmond, CA) and western transfer buffer [25 mmol/L Tris-HCl, pH 8.3; $192 \mathrm{mmol} / \mathrm{L}$ glycine; and $20 \%(\mathrm{v} / \mathrm{v})$ methanol]. Free binding sites were blocked in $5 \%(\mathrm{w} / \mathrm{v})$ bovine serum albumin in $20 \mathrm{mmol} / \mathrm{L}$ Tris- $\mathrm{HCl}$ buffer, $\mathrm{pH} 7.5$, containing $150 \mathrm{mmol} / \mathrm{L} \mathrm{NaCl}$ and $0.05 \%$ Tween 20, for 1 hour, after which LO antibody was applied for 2 hours. The horseradish peroxidase-conjugated secondary antibody was then applied for 1 hour. After extensive washing, protein bands detected by the antibodies were visualized with the Amersham ECL Western Blotting Detection Reagent (Little Chalfont, Buckinghamshire, UK). Membranes were then stripped in the 25 $\mathrm{mmol} / \mathrm{L}$ glycine- $\mathrm{HCl}, \mathrm{pH} 2.5$ buffer containing $2 \%$ SDS, and reprobed with $\beta$-actin antibody to confirm equal protein loading.

\section{2(S)HETE Measurements}

For assessment of 12(S)HETE, sciatic nerve samples were homogenized on ice in $15 \mathrm{mmol} / \mathrm{L}$ Tris- $\mathrm{HCl}$ buffer $(1: 100 \mathrm{w} / \mathrm{v})$ containing $140 \mathrm{mmol} / \mathrm{L} \mathrm{NaCl}, \mathrm{pH}$ 7.6, and centrifuged. 12(S)HETE was measured in supernatants with the 12(S)-hydroxyeicosatetraenoic acid [12(S)HETE] Enzyme Immuno Assay kit (Assay Designs, Ann Arbor, MI).

\section{Assessment of DAN}

\section{Tissue Preparation}

Mice were anesthetized with ketamine/xylazine and perfused transcardially with $25 \mathrm{ml}$ of heparinized saline followed by $25 \mathrm{ml}$ of modified Karnovsky's fixative containing $3 \%$ glutaraldehyde and $1 \%$ paraformaldehyde in sodium cacodylate buffer $\mathrm{pH}$ 7.4. Fixation was continued overnight at $4^{\circ} \mathrm{C}$ in the same fixative and the following day the SMG and CG were dissected together as a single block, cleaned of extraneous tissue, and rinsed in sodium cacodylate buffer. Tissue was postfixed in phosphate cacodylate-buffered $2 \% \mathrm{OsO}_{4}$ for 1 hour, dehydrated in graded ethanols with a final dehydration in propylene oxide, and embedded in EMbed-812 (Electron Microscopy Sciences, Hatfield, PA). One $\mu$ m-thick plastic sections were examined by light microscopy after staining with toluidine blue. Ultrathin sections ( 60 to $90 \mathrm{~nm}$ thick) of individual ganglia were cut onto formvar coated slot 
Table 1. Initial and Final Body Weights and Blood Glucose Concentrations in Nondiabetic Control and Diabetic $\mathrm{LO}^{+/+} \mathrm{Mice}^{-}$ Used for Diabetic Peripheral (Experiment 1) and Autonomic (Experiment 2) Neuropathy Studies

\begin{tabular}{|c|c|c|c|c|c|}
\hline \multirow[b]{2}{*}{ Group } & \multirow[t]{2}{*}{ Variable } & \multicolumn{2}{|c|}{ Body weight (g) } & \multicolumn{2}{|c|}{ Blood glucose (mmol/L) } \\
\hline & & Initial & Final & Initial & Final \\
\hline & & \multicolumn{4}{|c|}{ EXPERIMENT 1} \\
\hline $\begin{array}{l}\mathrm{LO}^{+/+} \\
\mathrm{LO}^{+/+} \text {diab } \\
\mathrm{LO}^{-/-} \\
\mathrm{LO}^{-/-} \text {diab }\end{array}$ & & $\begin{array}{l}26.4 \pm 0.7 \\
26.1 \pm 0.8 \\
25.9 \pm 0.7 \\
26.5 \pm 0.9\end{array}$ & $\begin{array}{r}40.4 \pm 1.6 \\
28.8 \pm 0.7^{\star *} \\
38.5 \pm 1.2 \\
29.5 \pm 0.8^{\star \star} \\
\text { E> }\end{array}$ & $\begin{aligned} 9.2 & \pm 0.8 \\
15.2 & \pm 1.0^{\star \star} \\
8.8 & \pm 0.7 \\
16.3 & \pm 1.3^{\star \star} \\
\text { VT } 2 & \end{aligned}$ & $\begin{aligned} 8.9 & \pm 0.5 \\
25.7 & \pm 1.3^{\star *} \\
9.1 & \pm 0.7 \\
27.2 & \pm 1.8^{\star \star}\end{aligned}$ \\
\hline $\begin{array}{l}\mathrm{LO}^{+/+} \\
\mathrm{LO}^{+/+} \text {diab } \\
\mathrm{LO}^{-/-} \\
\mathrm{LO}^{-/-} \text {diab }\end{array}$ & & $\begin{array}{l}25.1 \pm 0.9 \\
24.0 \pm 0.7 \\
26.6 \pm 0.7 \\
23.8 \pm 0.6\end{array}$ & $\begin{array}{l}32.4 \pm 0.8 \\
26.0 \pm 0.8^{\star *} \\
34.5 \pm 1.6 \\
25.6 \pm 0.4^{\star \star}\end{array}$ & $\begin{aligned} 8.5 & \pm 0.7 \\
15.8 & \pm 1.2^{\star \star} \\
8.0 & \pm 0.4 \\
14.9 & \pm 1.1^{\star \star}\end{aligned}$ & $\begin{array}{c}7.9 \pm 0.8 \\
32.1 \pm 0.8^{* *} \\
10.1 \pm 0.5 \\
30.5 \pm 1.2^{\text {** }}\end{array}$ \\
\hline
\end{tabular}

Data are expressed as means \pm SEM. $n=10$ to 12 per group in Experiment 1 , and $n=7$ to 10 per group in Experiment 2 . ${ }^{\star \star} P<0.01$ vs. nondiabetic control groups.

grids, which permits visualization of entire ganglionic cross sections. Sections were post stained with uranyl acetate and Venable's lead citrate and viewed with a JEOL model 1200EX electron microscope (JEOL, Tokyo, Japan). Digital images were acquired using the AMT Advantage HR (Advanced Microscopy Techniques, Danvers, MA).

\section{Quantification of Dystrophic Neurites}

Dystrophic elements are typically intimately related to neuronal perikarya representing axon termini as well as dendritic swellings and, therefore, we have routinely expressed their frequency as the ratio of numbers of lesions to numbers of nucleated neuronal cell bodies. This method, used in our previous studies, ${ }^{35-37,52,53}$ simplifies the ultrastructural examination of relatively large numbers of ganglia and identification of robust changes and substantially reduces the variability in assessments of intraganglionic lesion frequency. We recognize that the loss of substantial numbers of neurons would complicate this measurement; however, quantification of neuron numbers in short duration murine diabetes in other experiments fails to show substantial neuron loss, and the differences in neuritic dystrophy are so large in comparison that this is unlikely to complicate our analysis in these experiments. In our current animal studies an entire cross section of the SMG-CG was scanned at $\times 20,000$ magnification and the number of dystrophic neurites and synapses was determined by an investigator blinded to the identity of individual animals. Dystrophic neurites consist of swollen axons, synapses, dendritic spines, or dendrites containing a variety of organelles including: 1) axonal tubulovesicular aggregates; 2) axons with admixed normal and degenerating subcellular organelles and autophagic multivesicular bodies; 3) axonal neurofilaments; and, 4) nearly pure aggregates of minute dendritic mitochondria, which we have separated into large ( $>5 \mathrm{~mm}$ diameter) and small ( $<5 \mathrm{~mm}$ diameter) collections. The number of nucleated neurons (range, 50 to 100 neurons examined in each ganglionic cross section) was determined simultaneously. The frequency of ganglionic neuritic dystrophy was expressed as the ratio of number of dystrophic neurites to the number of nucleated neurons in the same cross section.

\section{Statistical Analysis}

The results are expressed as mean \pm SEM. Data were subjected to equality of variance $\mathrm{F}$ test, and then to log transformation, if necessary, before one-way analysis of variance. Where overall significance $(P<0.05)$ was attained, individual between group comparisons for multiple groups were made using the Student-Newman-Keuls multiple range test. When between-group variance differences could not be normalized by log transformation (datasets for body weights and blood glucose), the data were analyzed by the nonparametric Kruskal-Wallis oneway analysis of variance, followed by the Bonferroni/ Dunn test for multiple comparisons. Individual pair-wise comparisons of LO expression in nondiabetic and diabetic wild-type mice were made using the unpaired two-tailed Student's $t$-test. Significance was defined at $P \leq 0.05$.

\section{Results}

The initial (before STZ administration) body weights were similar in all experimental groups (Table 1). LO deficiency did not affect weight gain in either nondiabetic or diabetic mice. Weight gain during a 14-week study was similarly reduced in both diabetic wild-type and $\mathrm{LO}^{-1-}$ mice compared with the corresponding nondiabetic groups. Initial (after STZ administration) non-fasting blood glucose concentrations were $65 \%$ and $85 \%$ higher in diabetic wild-type and $\mathrm{LO}^{-/-}$mice than in the corresponding nondiabetic groups. Hyperglycemia progressed with the prolongation of diabetes, and the differences in final blood glucose concentrations between wild-type and $\mathrm{LO}^{-1-}$ mice with 14-week durations of diabetes and the corresponding nondiabetic groups reached 2.9-fold and 3.0-fold, respectively. In a similar fashion, weight gain during a 16-week study was similarly reduced in both diabetic wild-type and $\mathrm{LO}^{-1-}$ mice compared with the corresponding nondiabetic groups. LO gene deficiency 


\section{A}
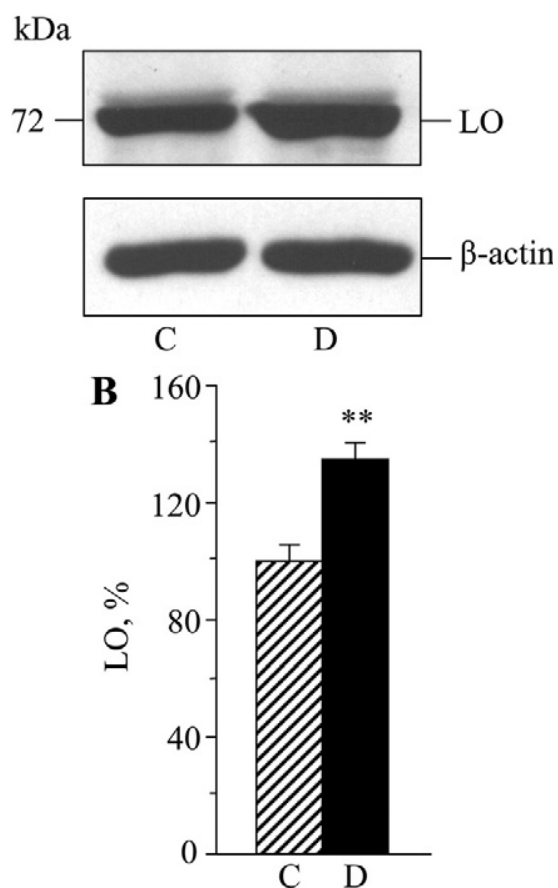

Figure 1. Representative Western blot analysis of sciatic nerve LO expression (A) and LO protein content (densitometry, B) in nondiabetic control and diabetic $\mathrm{LO}^{+/+}$mice. $\mathrm{C}-$ control; $\mathrm{D}$ - diabetic. Mean \pm SEM, $n=7$ to 10 per group. ${ }^{* *} P<0.01$ vs nondiabetic control group.

did not affect either initial severity of diabetic hyperglycemia or its progression.

Wild-type mice with 14-week duration of diabetes displayed clearly manifest LO upregulation in the peripheral nerve. Sciatic nerve LO expression was increased by $35 \%$ (Figure 1, A and B). 12(S)HETE concentration (a measure of LO activity) was increased 2.7-fold ( $P<0.05$, Figure 2). Note that peripheral nerve of $\mathrm{LO}^{-1-}$ mice also produced some $12(\mathrm{~S}) \mathrm{HETE}$, probably due to activity of other, nonleukocyte type, LOs. No statistically significant differences in sciatic nerve 12(S)HETE concentrations were found between diabetic LO-/- mice and the corresponding nondiabetic group $(P=0.55)$.

MNCV, SNCV, thermal response latencies, and tactile response thresholds (Table 2 ) were similar between nondiabetic $\mathrm{LO}^{+/+}$and $\mathrm{LO}^{-/-}$mice at the beginning of the study and at the 14-week time point, which indicates that LO deficiency does not interfere with normal peripheral nerve function. Note that both MNCV and SNCV were also similar between nondiabetic wild-type or $\mathrm{LO}^{-1-}$ mice at the beginning of the study and at the 14-week time point, which proves that diabetes-induced nerve conduction slowing did not develop due to affected peripheral nerve growth and maturation in either group. Wild-type mice with 14-week duration of diabetes displayed $28 \%$ MNCV and $20 \%$ SNCV deficits whereas LO deficiency essentially prevented diabetes-induced MNCV deficit $(1 \%)$ and significantly alleviated SNCV deficit $(9 \%, P<$ 0.05 vs. nondiabetic $\mathrm{LO}^{-1-}$ mice, and $<0.05$ vs. diabetic $\mathrm{LO}^{+/+}$mice). Both $\mathrm{LO}^{+/+}$and $\mathrm{LO}^{-/-}$mice with 14-week

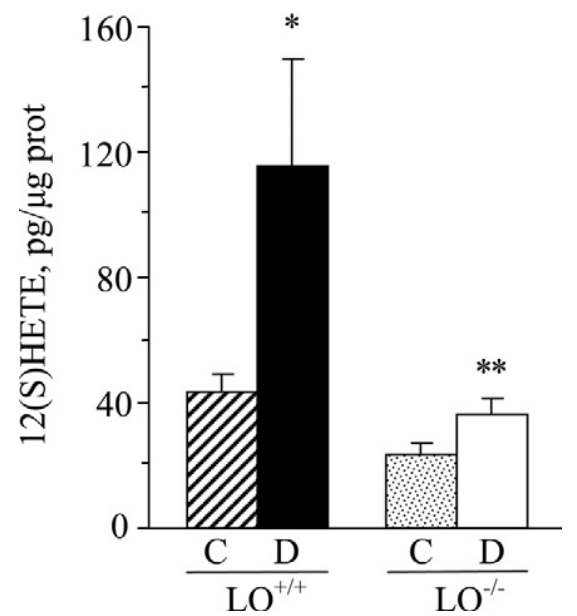

Figure 2. Sciatic nerve 12(S)HETE concentrations in nondiabetic control and diabetic $\mathrm{LO}^{+/+}$and $\mathrm{LO}^{-/-}$mice. $\mathrm{C}-$ control; $\mathrm{D}-$ diabetic. Mean $\pm \mathrm{SEM}$ $n=10$ to 11 per group. ${ }^{*} P<0.01$ vs. nondiabetic control group; ${ }^{* *} P<0.01$ vs diabetic $\mathrm{LO}^{+/+}$mice.

duration of diabetes developed clearly manifest thermal hypo-algesia; however, LO deficiency alleviated severity of this condition $(40 \%$ increase in paw withdrawal latency vs. $97 \%$ in diabetic $\mathrm{LO}^{+/+}$mice, $P<0.01$ ). In a similar fashion, both diabetic groups displayed tactile allodynia; however, this condition was less severe in diabetic LO-/ - mice than in diabetic wild-type mice $(18 \%$ and $86 \%$ reduction in tactile response thresholds, respectively, $P<0.01$ ).

Distal tibial nerve myelinated fiber diameter and myelin thickness were similar between non-diabetic $\mathrm{LO}^{+/+}$and $\mathrm{LO}^{-1-}$ mice at the beginning of the study $(5.52 \pm 0.12$ and $5.57 \pm 0.10 \mu \mathrm{m}$ and $1.78 \pm 0.05$ and $1.75 \pm 0.04$ $\mu \mathrm{m}$, respectively) and at the 14-week time point (Figure 3, $A$ and $B$ ), which suggests that LO deficiency does not affect morphometric characteristics of large myelinated fibers. Within-groups comparisons of the two variables at two time points (baseline and 14 weeks) also did not reveal any differences, which proves that diabetes-induced axonal atrophy did not develop in either group because of affected nerve growth and maturation. Myelinated fiber diameter and myelin thickness were reduced by $10 \%$ and $32 \%$ in the wild-type mice with diabetes of 14-week duration whereas LO deficiency completely prevented diabetes-associated axonal atrophy.

Intraepidermal nerve fiber densities were similar between nondiabetic $\mathrm{LO}^{+/+}$and $\mathrm{LO}^{-/-}$mice at the beginning of the study $(23.5 \pm 1.2$ and $22.5 \pm 1.1$ intraepidermal nerve fiber profiles/mm) and at the 14-week time point (Figure 4, A and B), which indicates that LO deficiency is not associated with loss or excessive sprouting of intraepidermal nerve fibers. Within-groups comparisons of the two variables at two time points (baseline and 14 weeks) also did not reveal any differences in intraepidermal nerve fiber densities, which suggests that diabetes-induced intraepidermal nerve fiber loss in either group was not a consequence of affected small sensory nerve fiber growth and maturation. Intraepidermal nerve fiber densities were reduced by $33 \%$ 
Table 2. Motor and Sensory Nerve Conduction Velocities, Thermal Response Latencies, and Tactile Response Thresholds in Nondiabetic Control and Diabetic $\mathrm{LO}^{+/+}$and $\mathrm{LO}^{-/-}$Mice

\begin{tabular}{|c|c|c|c|c|c|}
\hline Group & Variable & MNCV & SNCV & $\begin{array}{c}\text { Thermal response } \\
\text { latency (s) }\end{array}$ & $\begin{array}{c}\text { Tactile response } \\
\text { threshold }(\mathrm{g})\end{array}$ \\
\hline $\begin{array}{l}\mathrm{LO}^{+/+} \\
\mathrm{LO}^{-1-}\end{array}$ & & $\begin{array}{l}50.5 \pm 1.4 \\
51.0 \pm 1.1\end{array}$ & $\begin{array}{l}\text { Baseline }( \\
36.1 \pm 0.8 \\
35.5 \pm 0.5\end{array}$ & $\begin{array}{l}\text { nduction of diabetes } \\
\qquad \begin{array}{l}9.2 \pm 0.5 \\
9.4 \pm 0.6\end{array}\end{array}$ & $\begin{array}{l}2.73 \pm 0.17 \\
2.68 \pm 0.16\end{array}$ \\
\hline $\begin{array}{l}\mathrm{LO}^{+/+} \\
\mathrm{LO}^{+/+} \text {diab } \\
\mathrm{LO}^{-/-} \\
\mathrm{LO}^{-/-} \text {diab }\end{array}$ & & $\begin{array}{l}50.3 \pm 2.0 \\
36.4 \pm 1.1^{\dagger} \\
49.3 \pm 1.6 \\
48.9 \pm 2.7^{\S}\end{array}$ & $\begin{array}{l}35.8 \pm 1.1 \\
28.5 \pm 0.6^{\dagger} \\
34.4 \pm 0.4 \\
31.4 \pm 1.1^{\text {*† }}\end{array}$ & $\begin{array}{l}\text { time point } \\
\quad 9.6 \pm 0.4 \\
18.9 \pm 1.0^{\dagger} \\
10.0 \pm 0.4 \\
14.0 \pm 1.3^{\dagger \S}\end{array}$ & $\begin{array}{l}2.79 \pm 0.18 \\
0.40 \pm 0.06^{\dagger} \\
2.54 \pm 0.17 \\
2.08 \pm 0.16^{\star \S}\end{array}$ \\
\hline
\end{tabular}

Data are expressed as means \pm SEM. $n=10$ to 11 per group. ${ }^{*} P<0.05$ and ${ }^{\dagger} P<0.01$ vs. nondiabetic control groups. ${ }^{\ddagger} P<0.05$ and ${ }^{\S} P<0.01$ vs. diabetic $\mathrm{LO}^{+/+}$mice.

and $42 \%$ in wild-type and LO-/- mice with 14 -week durations of diabetes. LO gene deficiency did not prevent or alleviate small sensory nerve fiber degeneration.

SMG-CG of nondiabetic wild-type and $\mathrm{LO}^{-1-}$ mice displayed an unremarkable complement of principal sympathetic neurons surrounded by neuropil composed of an admixture of normal appearing axons and dendritic elements (Figure 5, A). In contrast, both wild-type and $\mathrm{LO}^{-1-}$ mice with diabetes of 16 -week duration contained dystrophic neurites in their prevertebral sympathetic ganglia (arrows, Figure 5B). Dystrophic neurites are frequently localized in immediate proximity to neuronal cell bodies, often within their satellite cell sheaths, causing displacement and distortion of perikaryal contours of targeted neurons. The light microscopic appearance of dystrophic neurites did not differ in diabetic wild-type and $\mathrm{LO}^{-1-}$ mice. Our study demonstrates rare actively degenerating neurons in the rodent model of DAN (arrow, Figure 5C). These degenerating neurons were present in both diabetic wild-type and diabetic $\mathrm{LO}^{-1-}$ mice (less than $1 \%$ of the principal sympathetic neurons in both groups), and were not found in either non-diabetic group. In addition, SMG-CG of both diabetic wild-type and $\mathrm{LO}^{-1-}$ mice contained neurons with patches of pale granular cytoplasm and subtle changes in nuclear chromatin, presumably entering the early phase of this degenerative process (Figure 5D), which were not found in
A

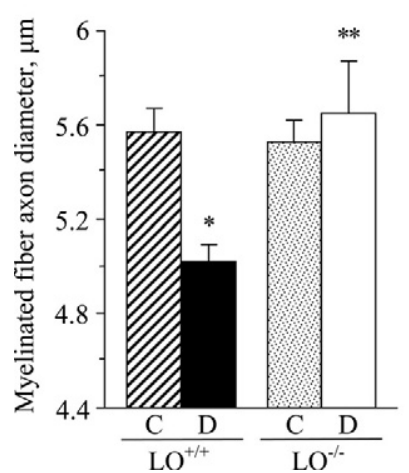

B

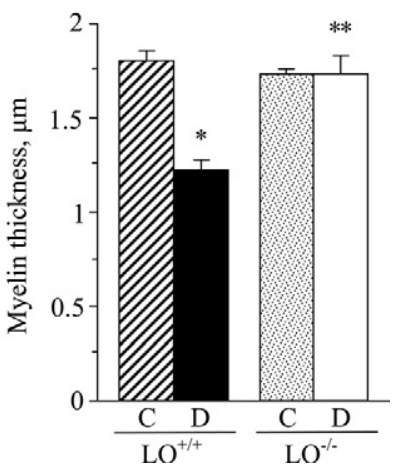

Figure 3. Myelinated fiber diameter (A) and myelin thickness (B) in nondiabetic control and diabetic $\mathrm{LO}^{+/+}$and $\mathrm{LO}^{-/-}$mice. $\mathrm{C}-$ control; D diabetic. Mean \pm SEM, $n=5$ to 10 per group. ${ }^{*} P<0.01$ vs nondiabetic control group; ${ }^{* * *} P<0.01$ vs diabetic $\mathrm{LO}^{+\gamma+}$ mice. either nondiabetic group. None of the ganglia of diabetic wild-type or $\mathrm{LO}^{-1-}$ mice displayed inflammatory infiltrates or associations of individual lymphocytes or macrophages with neuronal perikarya.

The results of SMG-CG ultrastructural examination (Figure 6, A-F) extend the light microscopic observations, demonstrating increased numbers of dystrophic neurites not visible by light microscopy. Neuritic dystrophy was typically manifest by swollen neurites intimately associated with the perikarya of principal sympathetic neurons (arrow, Figure 6A). Neuritic changes include the accumulation of a large number of tubulovesicular elements ranging from delicate to coarse with varied degrees of compaction (Figure 6B). Other massively enlarged neurites contained an admixture of mitochondria and tubulovesicular elements, often accompanied by autophagic vacuoles, surrounded by satellite Schwann cells (arrow, Figure 6C). Mitochondria of dystrophic neurites (arrow, Figure 6D) were significantly smaller than those of adjacent perikarya (arrowhead, Figure 6D). Mitochondria-rich dystrophic neurites often contained admixed autophagosomes with degraded mitochondria and membranes (Figure 6E). The ultrastructural appearance of degenerating neurons was characterized by perikaryal collections of small mitochondria, the loss of Niss substance, nuclear pallor and distortion of nuclear contours, shrinkage, accumulation of autophagic vacuoles, and accumulation of intranuclear debris (Figure 6F).

No statistically significant differences in the frequency of neuritic dystrophy were found between nondiabetic wild-type and $\mathrm{LO}^{-1-}$ mice, which indicates that $\mathrm{LO}$ gene deficiency is not associated with diabetes-like structural changes in SMG-CG (Figure 7). LO deficiency did not protect from the development of diabetes-induced dystrophic changes in SMG-CG, and the frequencies of neuritic dystrophy were increased 14.8-fold and 17.2-fold in diabetic wild-type and $\mathrm{LO}^{-1-}$ mice, respectively, compared with the corresponding nondiabetic groups (Figure 7).

Quantitative ultrastructural evaluation of neuritic dystrophy in SMG-CG revealed minor differences between wild-type and $\mathrm{LO}^{-1-}$ mice (Table 3). Both nondiabetic and diabetic wild-type and $\mathrm{LO}^{-1-}$ mice contained tubulovesicular aggregates and aggregates of large and small mitochondria (Table 3). The number of tubulove- 
$\mathbf{A}$

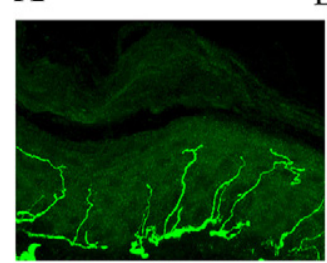

$\mathrm{C}$
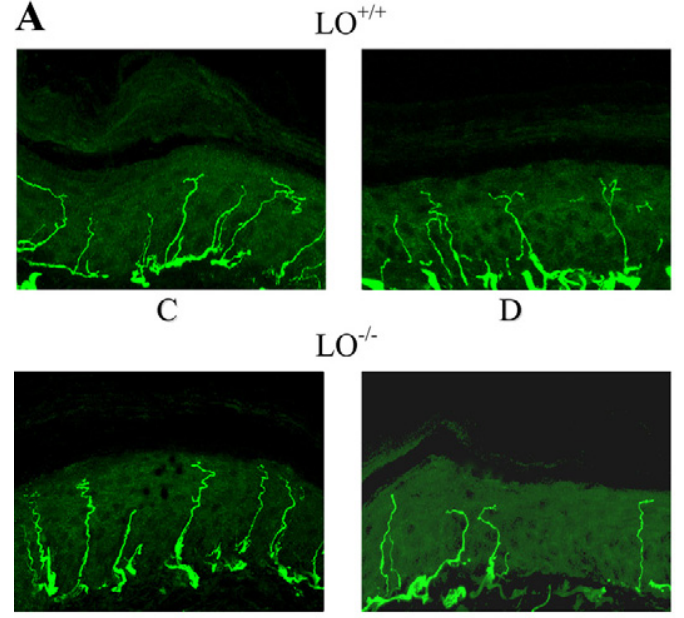

C
$\mathrm{LO}^{-/-}$

D

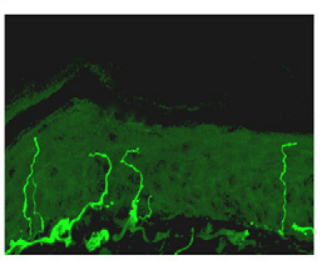

$\mathrm{D}$
B

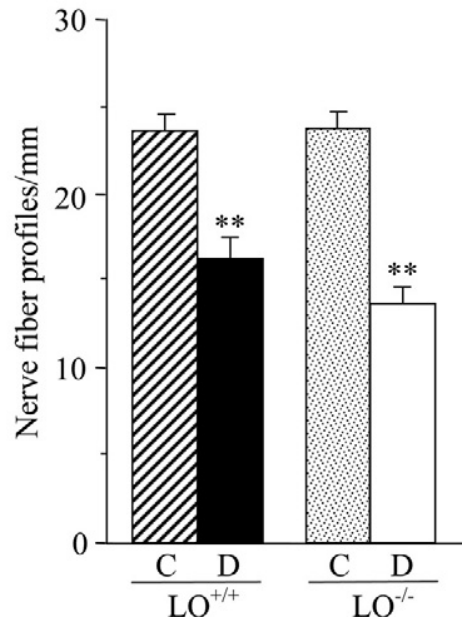

Figure 4. Representative images of intraepidermal nerve fiber profiles, magnification $\times 40(\mathbf{A})$, and intraepidermal nerve fiber densities $(\mathbf{B})$, in nondiabetic control and diabetic $\mathrm{LO}^{+/+}$and $\mathrm{LO}^{-1-}$ mice. Mean $\pm \mathrm{SEM}, n=10$ to 12 per group. $\mathrm{C}-$ control mice, $\mathrm{D}-$ diabetic mice. ${ }^{* *} P<$ 0.01 vs. nondiabetic control groups. sicular aggregates were similar in the two nondiabetic groups, although quite variable from animal to animal, whereas diabetic LO-/- mice contained 26\% fewer aggregates, than the diabetic wild-type mice. The number of admixed normal and degenerating subcellular organelles was $60 \%$ lower in dystrophic neurites of diabetic $\mathrm{LO}^{-1-}$ mice, and neurofilament aggregates were found in diabetic wild-type mice only. Diabetic wild-type and diabetic $\mathrm{LO}^{-1-}$ mice displayed degenerative changes in the cell bodies, which were not identified in any of the nondiabetic animals.

\section{Discussion}

The findings reported herein demonstrate an important role of LO in motor and sensory nerve conduction slowing, small sensory nerve fiber dysfunction, and axonal atrophy of large myelinated fibers characteristic for PDN. In contrast, this mechanism is not involved in diabetesassociated intraepidermal nerve fiber loss and apparently plays a minor role in structural changes in prevertebral ganglia associated with DAN.

With consideration of different opinions regarding mouse models applicable for studying diabetic neuropathy (compare 8, 18, 27, 32, 33, 51 and 54), it is important to emphasize that STZ-diabetic C57BI6/J mice displayed robust PDN, with clearly manifest MNCV and SNCV deficits, thermal hypoalgesia, intraepidermal nerve fiber loss, and axonal atrophy of distal tibial nerve myelinated fibers. These results are consistent with other studies, 8,27 including several from our group, ${ }^{18,33,51}$ demonstrating nerve conduction slowing, small nerve fiber dysfunction, and structural changes of myelinated and unmyelinated fibers in this mouse model. In addition to large and small
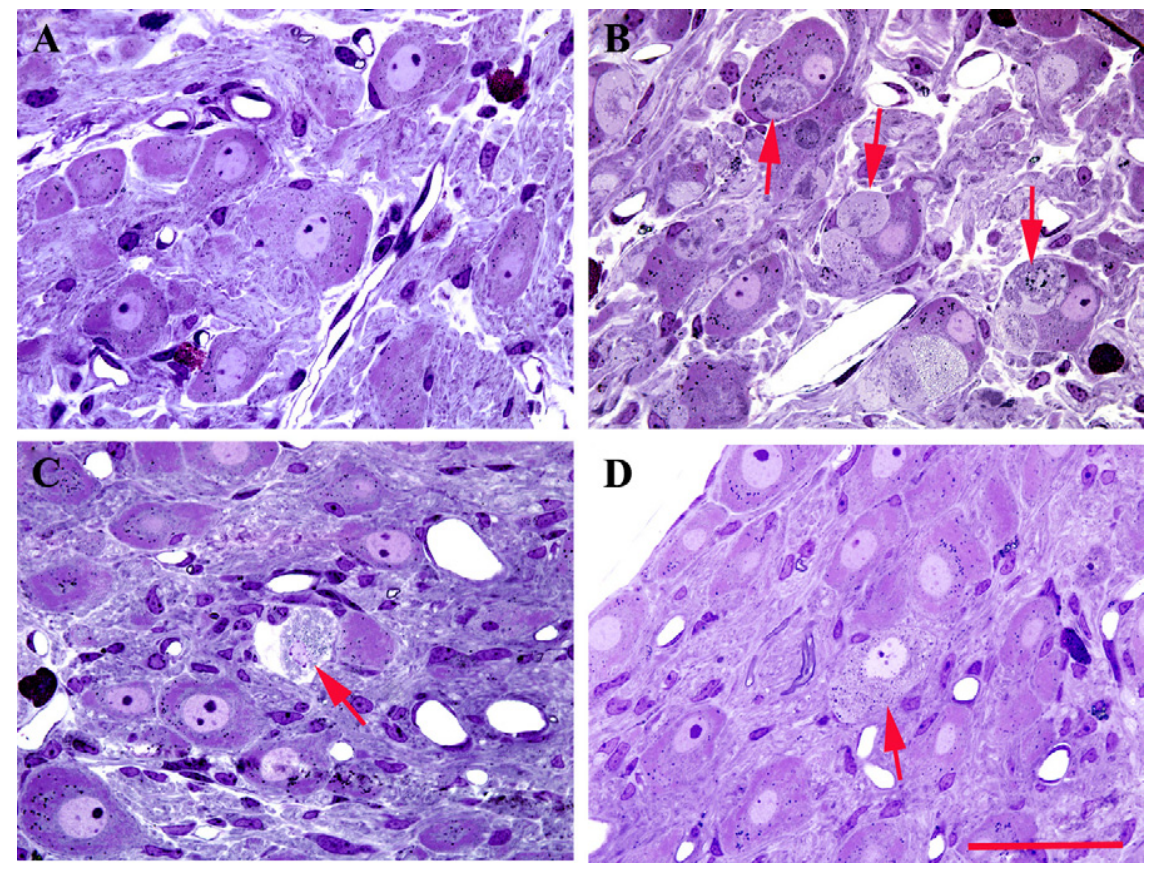

Figure 5. Light microscopic appearance of superior mesenteric-celiac ganglia in control and diabetic mice. Principal sympathetic neurons are surrounded by neuropil composed of an admixture of normal appearing axons and dendritic elements, in nondiabetic $\mathrm{LO}^{+/+}$and $\mathrm{LO}^{-1}$ mice (A). Dystrophic neurites (arrows, B) in diabetic $\mathrm{LO}^{+/+}$and $\mathrm{LO}^{-/-}$mice are localized in immediate proximity to neuronal cell bodies, often within their satellite cell sheaths, causing displacement and distortion of perikaryal contours of targeted neurons. Degenerating neuron (arrow, C) and a neuron early in the degenerative process (arrow, D) with pale granular cytoplasm and subtle changes in nuclear chromatin, were found in diabetic $\mathrm{LO}^{+/+}$and $\mathrm{LO}^{-\gamma}$ mice. Scale bar $=50$ microns. 

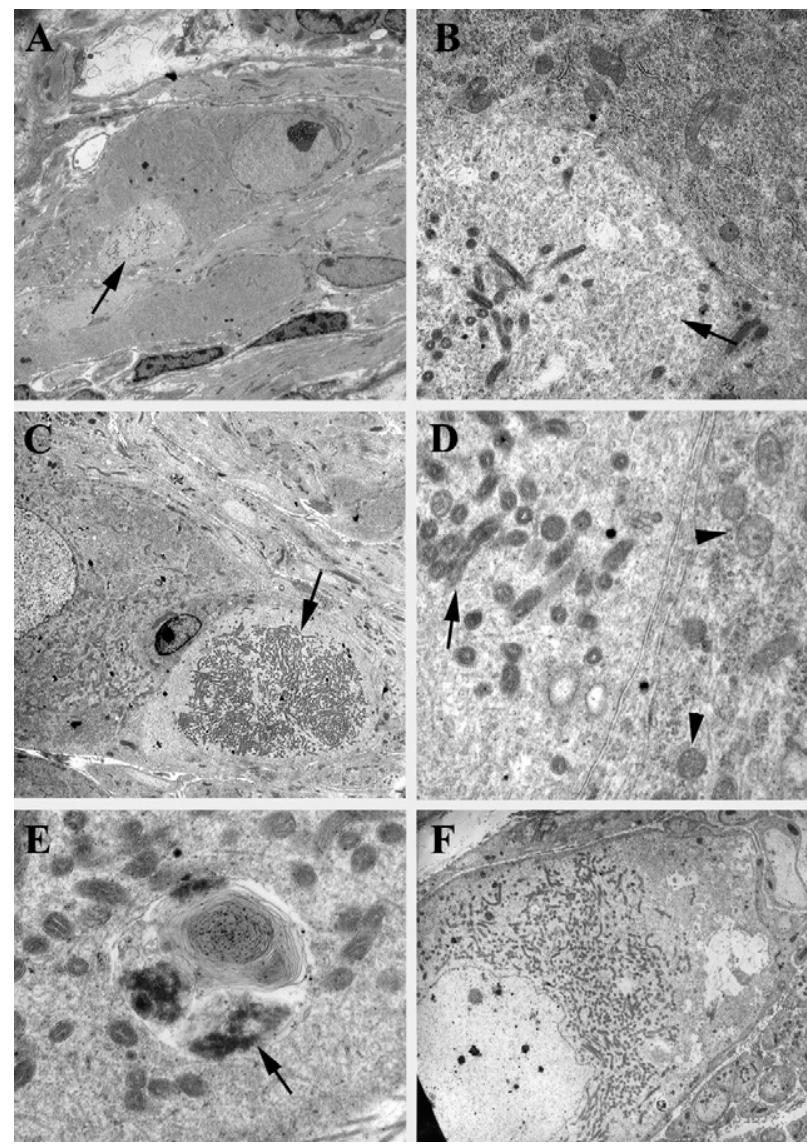

Figure 6. Ultrastructural appearance of superior mesenteric-celiac ganglia in diabetic $\mathrm{LO}^{+/+}$and $\mathrm{LO}^{-/-}$mice. A typical ultrastructural appearance of dystrophic neurites with terminal axonal and dendritic dilatations (arrow, $\mathbf{A}$ ) containing large numbers of tubulovesicular elements (arrow, B) is shown. The contours of the sympathetic perikaryon adjacent to a large dystrophic element are distorted (A), but the great majority of neuronal perikarya appear otherwise normal. A markedly enlarged dystrophic neurite (arrow, C) contains large numbers of mitochondria (arrow, D) of significantly smaller size than those in the adjacent perikaryon (arrowheads, D). Mitochondrial aggregates and engulfed membranous and osmiophilic material are contained within autophagosomes (arrow, E). A degenerating neuron (F) containing large numbers of small mitochondria is characterized by manifest cytoplasmic pallor, debris, and osmiophilic material and an abnormal irregular pale nucleus. Original magnification: $\times 3000(\mathbf{A}) ; \times 20,000(\mathbf{B}) ; \times 3000(\mathbf{C})$; $\times 40,000(\mathbf{D}) ; \times 50,000(\mathbf{E}) ; \times 5000(\mathbf{F})$

nerve fiber degeneration characteristic for PDN, diabetic C57Bl6/J mice displayed severe neuritic dystrophy in SMG-CG, the hallmark of DAN in mouse prevertebral sympathetic ganglia. In addition, their sympathetic autonomic ganglia contained a small (less than 1\%) number of degenerating neurons, which have only recently been identified in the Akita mouse model of DAN. ${ }^{53}$ These findings, consistent with other reports on the presence of diabetic erectile dysfunction, one of manifestations of DAN in urogenital tract, ${ }^{23,55}$ suggest that STZ-diabetic C57BI6/J mouse also represents an excellent model for studying both functional and structural changes characteristic for DAN, particularly that involving the innervation of the bowel. We have found that not all sympathetic ganglia exhibit the same pathological findings in mouse ${ }^{52,53}$ and other models and different subpopulations of axons, neurons, and mechanisms may be differentially affected in ganglia.

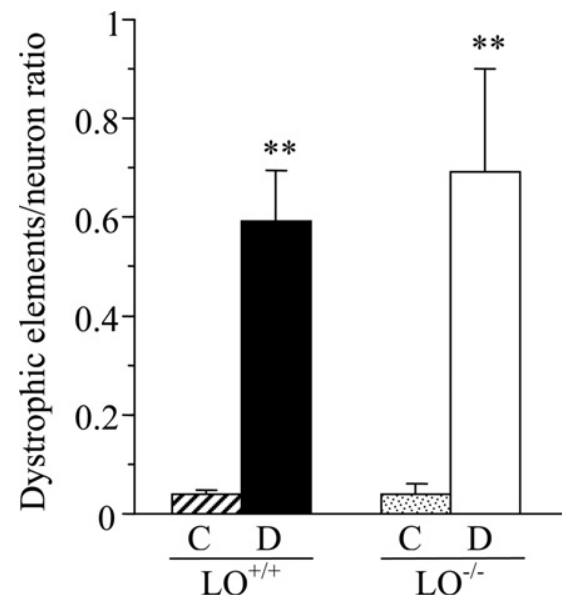

Figure 7. Frequencies of neuritic dystrophy in superior mesenteric-celiac ganglia (expressed as total number per nucleated neuron) show a dramatic increase in diabetic $\mathrm{LO}^{+/+}$and $\mathrm{LO}^{-1-}$ mice in comparison with nondiabetic control $\mathrm{LO}^{+/+}$and $\mathrm{LO}^{-/-}$mice. Mean \pm SEM, $n=7$ to $9,{ }^{* * *} P<0.01$ vs corresponding nondiabetic groups. Mean \pm SEM, $n=7$ to 10 per group. $\mathrm{C}$ - control mice, $\mathrm{D}$ - diabetic mice. ${ }^{* * *} P<0.01$ vs. nondiabetic control groups.

Sciatic nerve LO overexpression and 12(S)HETE accumulation were clearly manifest in STZ-diabetic wildtype mice. 12(H)SHETE was also identified in control and diabetic $\mathrm{LO}^{-1-}$ mice, probably due to activities of other, non-leukocyte type, $\mathrm{LO}(\mathrm{s})$. Note, however, that $\mathrm{LO}^{-1-}$ mice did not display diabetes-related 12(S)HETE accumulation in the peripheral nerve, where their 12(S)HETE concentrations were 3.3-fold lower than in the diabetic wild-type group. LO-derived 12(S)HETE is known to induce oxidative stress ${ }^{43,56,57}$ and pro-inflammatory response, ${ }^{49}$ to increase cytosolic $\mathrm{Ca}^{2+}, 58$ and to impair signal transduction through PKC and mitogen-activated protein kinase signaling cascades. ${ }^{43,56,57,59,60}$ Thus, LO overexpression and activation can lead to functional changes characteristic for PDN through multiple mechanisms. Studies of the role of $\mathrm{LO}$ in oxidative-nitrosative stress and mitogen-activated protein kinase activation in peripheral nerve, spinal cord, and DRG neurons are in progress in our laboratory. The relation between increased aldose reductase activity and LO overexpression and activation is also of great interest considering that 1) aldose reductase inhibition or gene deficiency has been found to correct or alleviate all diabetes-induced biochemical changes in somatic nervous system identified so far (reviewed in ${ }^{21,61}$; and 2) increased aldose reductase activity leads to activation of nuclear factor-kB and activator protein-1 as well as cytosolic $\mathrm{Ca}^{2+}$ accumulation (reviewed $\mathrm{in}^{61}$ ) ie, causes up-regulation of three factors essentially required for LO gene expression and activity. ${ }^{43,56}$ Also note that because LO is localized in both neural (DRG neurons and Schwann cells) and endothelial cells, it is likely to contribute to peripheral nerve dysfunction through both vascular and nonvascular mechanisms. Endothelial cells do accumulate $12(\mathrm{~S}) \mathrm{HETE}$ in response to high glucose, ${ }^{43,56}$ and LO up-regulation plays a key role in diabetes-induced endothelial dysfunction, ${ }^{43,56}$ an important factor in the pathogenesis of both experimental ${ }^{6,7,10,13-15,16,17,19,62-64}$ and clinical $^{65,66}$ PDN. 
Table 3. Subpopulations of Dystrophic Neurites in SMG-CG of Diabetic and Nondiabetic $\mathrm{LO}^{+/+}$and $\mathrm{LO}^{-/-} \mathrm{Mice}^{-1}$

\begin{tabular}{cccccc}
\hline Group & Tubulovesicles & Neurofilaments & Mixed organelles & Mitochondria A & Mitochondria B \\
\hline $\mathrm{LO}^{+/+}$ & $0.007 \pm 0.005$ & $0 \pm 0$ & $0.012 \pm 0.004$ & $0.003 \pm 0.003$ & $0.022 \pm 0.008$ \\
$\mathrm{LO}^{+/+}$diab & $0.043 \pm 0.021$ & $0.007 \pm 0.004^{*}$ & $0.06 \pm 0.017^{\dagger}$ & $0.083 \pm 0.023^{\star}$ & $0.398 \pm 0.064^{\dagger}$ \\
$\mathrm{LO}^{-/}$ & $0.007 \pm 0.007$ & $0 \pm 0$ & $0 \pm 0$ & $0.004 \pm 0.004$ & $0.029 \pm 0.012$ \\
$\mathrm{LO}^{-/-}$diab & $0.078 \pm 0.056$ & $0 \pm 0^{\ddagger}$ & $0.026 \pm 0.012^{\ddagger}$ & $0.094 \pm 0.039^{\dagger}$ & $0.481 \pm 0.125^{\dagger}$ \\
\hline
\end{tabular}

Dystrophic neurites were separated into subpopulations for each animal based on ultrastructural content and expressed as the ratio of numbers of lesions of each type/numbers of neurons, as calculated for each animal. Mitochondria-engorged neurites are presented as two groups on the basis of size of the dystrophic neurite: $A \geq 5 \mu \mathrm{m}$ and $\mathrm{B}<5 \mu \mathrm{m}$. Data are expressed as means $\pm \mathrm{SEM}, n=7$ to 10 per group. ${ }^{*} P<0.05$ and ${ }^{\dagger} P<0.01 \mathrm{vs}$. nondiabetic control groups. ${ }^{\ddagger} P<0.05$ vs. diabetic $\mathrm{LO}^{+/+}$mice.

The relations between diabetes-associated changes in peripheral nerve function and morphology deserve detailed discussion. Neither the present study, nor other findings in rat and mouse models that display both functional and morphological changes of PDN, answer the question of whether nerve conduction deficit is a direct consequence of axonal atrophy of large myelinated fibers, or others, unrelated to morphological changes, mechanisms. On the one hand, diabetes-associated MNCV and SNCV deficits are known to develop much earlier than axonal atrophy of large myelinated fibers, in both STZ-diabetic rats and STZ-diabetic mice. Nerve conduction slowing in rats and mice with a short-term (4to 8-week) diabetes is likely to result from neurovascular dysfunction ie, deficit in endoneurial nutritive blood flow and endoneurial hypoxia, and impaired vascular reactivity in vasa nervorum, rather than large motor and sensory fiber degeneration. $6,7,10,13,14,16,17,19,39,62-64$ On the other hand, our recent study in rats with diabetes of longer (12-week) duration identified highly significant positive correlations between MNCV/SNCV and myelin thickness. ${ }^{67}$ Clearly, more studies in animal models of diabetes displaying both nerve conduction deficit and morphometric changes, are needed to dissect the relations between large nerve fiber function and morphology, and, specifically in the context of the present findings, the mechanism(s) underlying a protective effect of LO gene deficiency on MNCV and SNCV. Intraepidermal nerve fiber density is emerging as a new approach for detection of small sensory nerve fiber degeneration in human subjects with diabetes and impaired glucose tolerance. ${ }^{68,69}$ Whereas in clinical studies, this variable has shown excellent correlations with sensory function, ${ }^{68,69}$ several experimental reports including the current study suggest that diabetes-induced thermal hypoalgesia does not necessarily develop as a consequence of intraepidermal nerve fiber loss $^{70}$ (reviewed in 71).

Despite being ineffective in delaying diabetes-associated small unmyelinated nerve fiber degeneration, LO gene deficiency completely prevented axonal atrophy of large myelinated fibers. Note that most experimental studies and clinical trials evaluated only one of the two phenomena, and thus it is not possible to compare our results with most of the literature. To our knowledge, only two published studies evaluated both large myelinated and small unmyelinated nerve fiber degeneration in diabetic mouse model. ${ }^{12,34}$ Receptors for advanced glycation end products deficiency ${ }^{12}$ and intranasal insulin ${ }^{34}$ prevented both diabetes-induced myelinated fiber ax- onal atrophy and reduction in intraepidermal nerve fiber density. Discordant effects of LO gene deficiency on axonal atrophy of large myelinated fibers and intraepidermal nerve fiber loss are hard to explain on the basis of current knowledge on LO. One can speculate that 12(S)HETE and its numerous lipid-like derivatives concentrate in myelinated fibers due to formation of hydrophobic bonds with lipid components of myelin sheath.

Our previous studies identified differences in pathogenetic mechanisms underlying PDN and DAN. In particular, whereas SDH inhibition or gene deficiency did not result in exacerbation of neurovascular dysfunction and nerve conduction deficit associated with PDN, 6,36,72,73 it was associated with a dramatic increase in neuroaxonal dystrophic changes in ileal mesenteric nerves and sympathetic ganglia characteristic for DAN. ${ }^{36}$ Nerve growth factor and neurotrophin-3, which have been reported to alleviate multiple manifestations of PDN, ${ }^{27,74-76}$ appeared completely ineffective in preventing the aforementioned structural changes associated with DAN. ${ }^{77}$ Zucker diabetic fatty rats with hyperglycemia and hyperinsulinemia developed functional and structural changes characteristic for PDN, ${ }^{70}$ but no neuroaxonal dystrophy of ileal mesenteric nerves and sympathetic autonomic ganglia. $^{37}$ These findings suggest that insulinopenia, impaired neurotrophic support, and other factors (potentially, sorbitol accumulation and resulting osmotic stress) play different roles in PDN and DAN. In the present study, LO gene deficiency, which essentially prevented diabetes-induced MNCV and SNCV deficit and completely protected from axonal atrophy of distal tibial nerve myelinated fibers, appeared to play minor role in structural changes characteristic for DAN. Both STZ-diabetic wildtype and LO-/- mice developed severe neuritic dystrophic changes in SMG-CG, similar to those observed in STZ-diabetic rats ${ }^{35,36}$ and nonobese diabetic ${ }^{52}$ and diabetic Akita $^{53}$ mice. The frequency of neuritic dystrophy was similar between the two diabetic groups. SMG-CG of diabetic wild-type and $\mathrm{LO}^{-1-}$ mice displayed similar small (less than 1\%) numbers of degenerating neurons as well as similar numbers of neurons with pale granular cytoplasm and subtle changes in nuclear chromatin possibly representing the early phase of the degenerative process. Note that ultrastructural evaluation of SMG-CG revealed less significant accumulation of tubulovesicular aggregates and admixed normal and degenerating subcellular organelles, and lack of neurofilaments in diabetic $\mathrm{LO}^{-1-}$ mice. However, in general, the role of LO in dia- 
betes-induced neuritic dystrophy in SMG-CG appears minor. The contribution of LO to functional changes associated with any kind of DAN has never been explored.

The selection of proper endpoints for neuropathy clinical trials remains a difficult task because some measures respond to a pathogenetic treatment, whereas others do not. For example, a 52-week, multicenter, placebo-controlled, double-blind, parallel group study revealed beneficial effect of the aldose reductase inhibitor fidarestat on two electrophysiological measures (ie, median nerve F-wave conduction velocity and minimal latency) out of eight used. ${ }^{78}$ In a similar fashion, a 6-month, randomized, double-masked, placebo-controlled study evaluating the effects of the protein kinase $C-\beta$ inhibitor ruboxistaurin on skin microvascular blood flow and other measures of diabetic peripheral neuropathy revealed beneficial effect of the drug on the Neuropathy Total Symptom Score, the Norfolk QOL-DN symptom subscore and total score, and endothelium-dependent and C-fiber-mediated skin microvascular blood flow, but not nerve fiber morphometry, quantitative sensory testing, quantitative autonomic function testing, and nerve conduction measures. ${ }^{79}$ These two examples suggest that future clinical neuropathy trials should include multiple endpoints, and that selection of those should be based on detailed knowledge of pathogenetic mechanisms underlying functional and structural changes characteristic for PDN and DAN. Whereas probability of discrepancy between the results of animal model studies and human trials is never excluded, the findings of the present study suggests that future clinical trials of LO inhibitors are more likely to reveal a beneficial effect on electrophysiology and sural nerve morphometry, rather than on quantitative sensory testing measures or intraepidermal nerve fiber density.

In conclusion, whereas LO overexpression and activation provides an important contribution to functional changes characteristic for both large and small fiber PDN, and axonal atrophy of large myelinated fibers, its role in intraepidermal nerve fiber loss and sympathetic autonomic ganglion neuritic dystrophy and neuronal degeneration is minor. The findings justify future studies of the role for LO in functional changes associated with DAN, and of interactions between LO and other molecular mechanisms underlying diabetes-induced peripheral nerve demyelination. They provide the rationale for development of LO inhibitors and LO inhibitor-containing combination therapies.

\section{Acknowledgments}

We thank Dr. Douglas E. Wright (University of Kansas Medical Center, Kansas City, Kansas) and Dr. Gary L. Pittenger (Eastern Virginia Medical School, Norfolk, Virginia) for valuable recommendations regarding intraepidermal nerve fiber density measurements and Ms. Karen Green for technical assistance with ultrastructural analysis.

\section{References}

1. National Institutes of Diabetes and Digestive and Kidney Diseases: Diabetes in America, ed 2, NIH Publication No. 95-1468. Bethesda, Maryland, NIH, 1995, pp. 339-349.

2. Boulton AJ, Vinik Al, Arezzo JC, Bril V, Feldman EL, Freeman R, Malik RA, Maser RE, Sosenko JM, Ziegler D: Diabetic neuropathies: a statement by the American Diabetes Association. Diabetes Care 2005, 28:956-962

3. Vinik Al, Maser RE, Mitchell BD, Freeman R: Diabetic autonomic neuropathy. Diabetes Care 2003, 26:1553-1579

4. The effect of intensive diabetes therapy on the development and progression of neuropathy. The Diabetes Control and Complications Trial Research Group. Ann Intern Med 1995, 122:561-568

5. Davidson JA: Treatment of the patient with diabetes: importance of maintaining target $\mathrm{HbA}(1 \mathrm{c})$ levels. Curr Med Res Opin 2004, 20:1919-1927

6. Cameron NE, Cotter MA, Basso M, Hohman TC: Comparison of the effects of inhibitors of aldose reductase and sorbitol dehydrogenase on neurovascular function, nerve conduction and tissue polyol pathway metabolites in streptozotocin-diabetic rats. Diabetologia 1997, 40:271-281

7. Obrosova IG, Van Huysen C, Fathallah L, Cao XC, Greene DA Stevens MJ: An aldose reductase inhibitor reverses early diabetesinduced changes in peripheral nerve function, metabolism, and antioxidative defense. FASEB J 2002, 16:123-125

8. Ho EC, Lam KS, Chen YS, Yip JC, Arvindakshan M, Yamagishi S, Yagihashi S, Oates PJ, Ellery CA, Chung SS, Chung SK: Aldose reductase-deficient mice are protected from delayed motor nerve conduction velocity, increased c-Jun NH2-terminal kinase activation, depletion of reduced glutathione, increased superoxide accumulation, and DNA damage. Diabetes 2006, 55:1946-1953

9. Wada R, Nishizawa $Y$, Yagihashi $N$, Takeuchi $M$, Ishikawa $Y$ Yasumura K, Nakano M, Yagihashi S: Effects of OPB-9195, antiglycation agent, on experimental diabetic neuropathy. Eur J Clin Invest 2001, 31:513-520

10. Cameron NE, Gibson TM, Nangle MR, Cotter MA: Inhibitors of advanced glycation end product formation and neurovascular dysfunction in experimental diabetes. Ann NY Acad Sci 2005, 1043:784-792

11. Bierhaus A, Haslbeck KM, Humpert PM, Liliensiek B, Dehmer T, Morcos M, Sayed AA, Andrassy M, Schiekofer S, Schneider JG, Schulz JB, Heuss D, Neundörfer B, Dierl S, Huber J, Tritschler H, Schmidt AM, Schwaninger M, Haering HU, Schleicher E, Kasper M, Stern DM, Arnold B, Nawroth PP: Loss of pain perception in diabetes is dependent on a receptor of the immunoglobulin superfamily. $\mathrm{J}$ Clin Invest 2004, 114:1741-1751

12. Toth C, Rong LL, Yang C, Martinez J, Song F, Ramji N, Brussee V, Liu W, Durand J, Nguyen MD, Schmidt AM, Zochodne DW: Receptor for advanced glycation end products (RAGEs) and experimental diabetic neuropathy. Diabetes 2008, 57:1002-1017

13. Cameron NE, Cotter MA, Jack AM, Basso MD, Hohman TC: Protein kinase $\mathrm{C}$ effects on nerve function, perfusion. $\mathrm{Na}(+), \mathrm{K}(+)$-ATPase activity and glutathione content in diabetic rats. Diabetologia 1999, 42:1120-1130

14. Nakamura J, Kato K, Hamada Y, Nakayama M, Chaya S, Nakashima E, Naruse K, Kasuya Y, Mizubayashi R, Miwa K, Yasuda Y, Kamiya H, lenaga K, Sakakibara F, Koh N, Hotta N: A protein kinase C-betaselective inhibitor ameliorates neural dysfunction in streptozotocininduced diabetic rats. Diabetes 1999, 48:2090-2095

15. Price SA, Agthong S, Middlemas AB, Tomlinson DR: Mitogen-activated protein kinase p38 mediates reduced nerve conduction velocity in experimental diabetic neuropathy: interactions with aldose reductase. Diabetes 2004, 53:1851-1856

16. Cameron NE, Tuck Z, McCabe L, Cotter MA: Effect of the hydroxyl radical scavenger, dimethylthiourea, on peripheral nerve tissue perfusion, conduction velocity and nociception in experimental diabetes. Diabetologia 2001, 44:1161-1169

17. Coppey LJ, Gellett JS, Davidson EP, Dunlap JA, Lund DD, Yorek MA: Effect of antioxidant treatment of streptozotocin-induced diabetic rats on endoneurial blood flow, motor nerve conduction velocity, and vascular reactivity of epineurial arterioles of the sciatic nerve. Diabetes 2001, 50:1927-1937

18. Obrosova IG, Mabley JG, Zsengellér Z, Charniauskaya T, Abatan OI, Groves JT, Szabó C: Role for nitrosative stress in diabetic 
neuropathy: evidence from studies with a peroxynitrite decomposition catalyst. FASEB J 2005, 19:401-403

19. Obrosova IG, Li F, Abatan OI, Forsell MA, Komjáti K, Pacher P, Szabó C, Stevens MJ: Role of poly(ADP-ribose) polymerase activation in diabetic neuropathy. Diabetes 2004, 53:711-720

20. Obrosova IG, Xu W, Lyzogubov VV, Inytska O, Mashtalir N, Vareniuk I, Pavlov IA, Zhang J, Slusher B, Drel VR: PARP inhibition or gene deficiency counteracts intraepidermal nerve fiber loss and neuropathic pain in advanced diabetic neuropathy. Free Radic Biol Med 2008, 44:972-981

21. Obrosova IG: Diabetes and the peripheral nerve. Biochim Biophys Acta 2009, 1792:931-940

22. Keegan A, Jack AM, Cotter MA, Cameron NE: Effects of aldose reductase inhibition on responses of the corpus cavernosum and mesenteric vascular bed of diabetic rats. J Cardiovasc Pharmacol 2000, 35:606-613

23. Nangle MR, Cotter MA, Cameron NE: Effects of the peroxynitrite decomposition catalyst. FeTMPyP, on function of corpus cavernosum from diabetic mice. Eur J Pharmacol 2004, 502:143-148

24. Gibson TM, Cotter MA, Cameron NE: Effects of poly(ADP-ribose) polymerase inhibition on dysfunction of non-adrenergic non-cholinergic neurotransmission in gastric fundus in diabetic rats. Nitric Oxide 2006, 15:344-350

25. Sagara M, Satoh J, Wada R, Yagihashi S, Takahashi K, Fukuzawa M, Muto G, Muto Y, Toyota T: Inhibition of development of peripheral neuropathy in streptozotocin-induced diabetic rats with $\mathrm{N}$-acetylcysteine. Diabetologia 1996, 39:263-269

26. Kato N, Mizuno K, Makino M, Suzuki T, Yagihashi S: Effects of 15-month aldose reductase inhibition with fidarestat on the experimental diabetic neuropathy in rats. Diabetes Res Clin Pract 2000, 50:77-85

27. Yagihashi S, Yamagishi SI, Wada Ri R, Baba M, Hohman TC, YabeNishimura C, Kokai Y: Neuropathy in diabetic mice overexpressing human aldose reductase and effects of aldose reductase inhibitor. Brain 2001, 124:2448-2458

28. Stevens MJ, Zhang W, Li F, Sima AA: C-peptide corrects endoneurial blood flow but not oxidative stress in type 1 BB/Wor rats. Am J Physiol Endocrinol Metab 2004, 287:E497-E505

29. Drel VR, Mashtalir N, Innytska O, Shin J, Li F, Lyzogubov VV, Obrosova IG: The leptin-deficient (ob/ob) mouse: a new animal model of peripheral neuropathy of type 2 diabetes and obesity. Diabetes 2006 , 55:3335-3343

30. Kamiya H, Zhang W, Ekberg K, Wahren J, Sima AA: C-Peptide reverses nociceptive neuropathy in type 1 diabetes. Diabetes 2006, 55:3581-3587

31. Toth C, Brussee V, Zochodne DW: Remote neurotrophic support of epidermal nerve fibres in experimental diabetes. Diabetologia 2006, 49:1081-1088

32. Christianson JA, Ryals JM, Johnson MS, Dobrowsky RT, Wright DE: Neurotrophic modulation of myelinated cutaneous innervation and mechanical sensory loss in diabetic mice. Neuroscience 2007 145:303-313

33. Drel VR, Pacher P, Vareniuk I, Pavlov IA, Ilnytska O, Lyzogubov VV, Bell SR, Groves JT, Obrosova IG: Evaluation of the peroxynitrite decomposition catalyst Fe(III) tetra-mesitylporphyrin octasulfonate on peripheral neuropathy in a mouse model of type 1 diabetes. Int J Mol Med 2007, 20:783-792

34. Francis G, Martinez J, Liu W, Nguyen T, Ayer A, Fine J, Zochodne D, Hanson LR, Frey WH 2nd, Toth C: Intranasal insulin ameliorates experimental diabetic neuropathy. Diabetes 2009, 58:934-945

35. Schmidt RE, Dorsey DA, Beaudet LN, Plurad SB, Parvin CA, Miller MS: Insulin-like growth factor I reverses experimental diabetic autonomic neuropathy. Am J Pathol 1999, 155:1651-1660

36. Schmidt RE, Dorsey DA, Beaudet LN, Plurad SB, Parvin CA, Yarasheski KE, Smith SR, Lang HJ, Williamson JR, Ido Y: Inhibition of sorbitol dehydrogenase exacerbates autonomic neuropathy in rats with streptozotocin-induced diabetes. J Neuropathol Exp Neurol 2001, 60:1153-1169

37. Schmidt RE, Dorsey DA, Beaudet LN, Peterson RG: Analysis of the Zucker Diabetic Fatty (ZDF) type 2 diabetic rat model suggests a neurotrophic role for insulin/lGF-I in diabetic autonomic neuropathy. Am J Pathol 2003, 163:21-28

38. Kuruvilla R, Peterson RG, Kincaid JC, Eichberg J: Evening primrose oil treatment corrects reduced conduction velocity but not depletion of arachidonic acid in nerve from streptozotocin-induced diabetic rats. Prostaglandins Leukot Essent Fatty Acid 1998, 59:195-202

39. Pop-Busui R, Marinescu V, Van Huysen C, Li F, Sullivan K, Greene DA, Larkin D, Stevens MJ: Dissection of metabolic, vascular, and nerve conduction interrelationships in experimental diabetic neuropathy by cyclooxygenase inhibition and acetyl-L-carnitine administration. Diabetes 2002, 51:2619-2628

40. Kellogg AP, Wiggin TD, Larkin DD, Hayes JM, Stevens MJ, Pop-Busui $\mathrm{R}$ : Protective effects of cyclooxygenase- 2 gene inactivation against peripheral nerve dysfunction and intraepidermal nerve fiber loss in experimental diabetes. Diabetes 2007, 56:2997-3005

41. Kellogg AP, Converso K, Wiggin T, Stevens M, Pop-Busui R: Effects of cyclooxygenase-2 gene inactivation on cardiac autonomic and left ventricular function in experimental diabetes. Am J Physiol Heart Circ Physiol 2009, 296:H453-H461

42. Ramos KM, Jiang $\mathrm{Y}$, Svensson $\mathrm{Cl}$, Calcutt NA: Pathogenesis of spinally mediated hyperalgesia in diabetes. Diabetes 2007, 56:1569-1576

43. Natarajan R, Nadler JL: Lipid inflammatory mediators in diabetic vascular disease. Arterioscler Thromb Vasc Biol 2004, 24:1542-1548

44. Yuan H, Lanting L, Xu ZG, Li SL, Swiderski P, Putta S, Jonnalagadda M, Kato M, Natarajan R: Effects of cholesterol-tagged small interfering RNAs targeting 12/15-lipoxygenase on parameters of diabetic nephropathy in a mouse model of type 1 diabetes. Am J Physiol Renal Physiol 2008, 295:F605-F617

45. Obrosova IG, Lyzogubov VV, Marchand J, Bai F, Nadler JL, Drel VR: Role for 12/15-lipoxygenase in diabetic neuropathy. Diabetes 2006 , 55 (Suppl. 1):A188

46. Obrosova IG, Ilnytska O, Lyzogubov VV, Pavlov IA, Mashtalir N Nadler JL, Drel VR: High-fat diet induced neuropathy of pre-diabetes and obesity: effects of "healthy" diet and aldose reductase inhibition. Diabetes 2007, 56:2598-2608

47. Prasad VV, Nithipatikom K, Harder DR: Ceramide elevates 12-hydroxy-eicosatetraenoic acid levels and upregulates 12-lipoxygenase in rat primary hippocampal cell cultures containing predominantly astrocytes. Neurochem Int 2008, 53:220-229

48. Li J, Wang H, Rosenberg PA: Vitamin K prevents oxidative cell death by inhibiting activation of 12-lipoxygenase in developing oligodendrocytes. J Neurosci Res 2009, 87:1997-2005

49. Nunemaker CS, Chen M, Pei H, Kimble SD, Keller SR, Carter JD, Yang Z, Smith KM, Wu R, Bevard MH, Garmey JC, Nadler JL: 12Lipoxygenase-knockout mice are resistant to inflammatory effects of obesity induced by Western diet. Am J Physiol Endocrinol Metab 2008, 295:E1065-E1075

50. Gubitosi-Klug RA, Talahalli R, Du Y, Nadler JL, Kern TS: 5-Lipoxygenase, but not 12/15-lipoxygenase, contributes to degeneration of retinal capillaries in a mouse model of diabetic retinopathy. Diabetes 2008, 57:1387-1393

51. Vareniuk I, Pavlov IA, Obrosova IG: Inducible nitric oxide synthase gene deficiency counteracts multiple manifestations of peripheral neuropathy in a streptozotocin-induced mouse model of diabetes. Diabetologia 2008, 51:2126-2133

52. Schmidt RE, Dorsey DA, Beaudet LN, Frederick KE, Parvin CA Plurad SB, Levisetti MG: Non-obese diabetic mice rapidly develop dramatic sympathetic neuritic dystrophy: a new experimental mode of diabetic autonomic neuropathy. Am J Pathol 2003, 163:2077-2091

53. Schmidt RE, Green KG, Snipes LL, Feng D: Neuritic dystrophy and neuronopathy in Akita (Ins $2^{\text {Akita }}$ ) diabetic mouse sympathetic ganglia. Exp Neurol 2009, 216:207-218

54. Sullivan KA, Hayes JM, Wiggin TD, Backus C, Su Oh S, Lentz SI Brosius F 3rd, Feldman EL: Mouse models of diabetic neuropathy. Neurobiol Dis 2007, 28:276-285

55. Nangle MR, Cotter MA, Cameron NE: Effects of rosuvastatin on nitric oxide-dependent function in aorta and corpus cavernosum of diabetic mice: relationship to cholesterol biosynthesis pathway inhibition and lipid lowering. Diabetes 2003, 52:2396-2402

56. Natarajan R, Nadler JL: Lipoxygenases and lipid signaling in vascular cells in diabetes. Front Biosci 2003, 8:783-795

57. Praticò D, Zhukareva V, Yao Y, Uryu K, Funk CD, Lawson JA, Trojanowski JQ, Lee VM: 12/15-lipoxygenase is increased in Alzheimer's disease: possible involvement in brain oxidative stress. Am J Pathol 2004, 164:1655-1662

58. Rao GN, Baas AS, Glasgow WC, Eling TE, Runge MS, Alexander RW: Activation of mitogen-activated protein kinases by arachidonic acid 
and its metabolites in vascular smooth muscle cells. J Biol Chem 1994, 269:32586-32591

59. Natarajan R, Reddy MA, Malik KU, Fatima S, Khan BV: Signaling mechanisms of nuclear factor-kappa $\beta$-mediated activation of inflammatory genes by 13-hydroperoxyoctadecadienoic acid in cultured vascular smooth muscle cells. Arterioscler Thromb Vasc Biol 2001, 21:1408-1413

60. Reddy MA, Thimmalapura PR, Lanting L, Nadler JL, Fatima S, Natarajan R: The oxidized lipid and lipoxygenase product 12(S)hydroxyeicosa-tetraenoic acid induces hypertrophy and fibronectin transcription in vascular smooth muscle cells via p38 MAPK and CAMP response element-binding protein activation. Mediation of angiotensin II effects. J Biol Chem 2002, 277:9920-9928

61. Obrosova IG: Increased sorbitol pathway activity generates oxidative stress in tissue sites for diabetic complications. Antioxid Redox Signal 2005, 7:1543-1552

62. Nagamatsu M, Nickander KK, Schmelzer JD, Raya A, Wittrock DA, Tritschler H, Low PA: Lipoic acid improves nerve blood flow, reduces oxidative stress, and improves distal nerve conduction in experimental diabetic neuropathy. Diabetes Care 1995, 18:1160-1167

63. Nakae M, Kamiya $H$, Naruse $K$, Horio $N$, Ito $Y$, Mizubayashi $R$, Hamada Y, Nakashima E, Akiyama N, Kobayashi Y, Watarai A, Kimura N, Horiguchi M, Tabata Y, Oiso Y, Nakamura J: Effects of basic fibroblast growth factor on experimental diabetic neuropathy in rats. Diabetes 2006, 55:1470-1477

64. Shibata T, Naruse K, Kamiya H, Kozakae M, Kondo M, Yasuda Y, Nakamura N, Ota K, Tosaki T, Matsuki T, Nakashima E, Hamada Y, Oiso $\mathrm{Y}$, Nakamura J: Transplantation of bone marrow-derived mesenchymal stem cells improves diabetic polyneuropathy in rats. Diabetes 2008, 57:3099-3107

65. Tesfaye S, Harris N, Jakubowski JJ, Mody C, Wilson RM, Rennie IG, Ward JD: Impaired blood flow and arterio-venous shunting in human diabetic neuropathy: a novel technique of nerve photography and fluorescein angiography. Diabetologia 1993, 36:1266-1274

66. Veves A, Akbari CM, Primavera J, Donaghue VM, Zacharoulis D, Chrzan JS, DeGirolami U, LoGerfo FW, Freeman R: Endothelial dysfunction and the expression of endothelial nitric oxide synthetase in diabetic neuropathy, vascular disease, and foot ulceration. Diabetes 1998, 47:457-463

67. Drel VR, Lupachyk S, Shevalye H, Vareniuk I, Xu W, Zhang J, Delamere NA, Shahidullah M, Slusher B, Obrosova IG: New therapeutic and biomarker discovery for peripheral diabetic neuropathy: PARP inhibitor, nitrotyrosine, and tumor necrosis factor-\{alpha\}. Endocrinology, 2010, [Epub ahead of print].

68. Pittenger GL, Ray M, Burcus NI, McNulty P, Basta B, Vinik Al: Intra- epidermal nerve fibers are indicators of small-fiber neuropathy in both diabetic and nondiabetic patients. Diabetes Care. 2004, 27:1974-1979

69. Quattrini C, Tavakoli M, Jeziorska M, Kallinikos P, Tesfaye S, Finnigan J, Marshall A, Boulton AJ, Efron N, Malik RA: Surrogate markers of small fiber damage in human diabetic neuropathy. Diabetes 2007, 56:2148-2154

70. Brussee V, Guo G, Dong Y, Cheng C, Martinez JA, Smith D, Glazner GW, Fernyhough P, Zochodne DW: Distal degenerative sensory neuropathy in a long-term type 2 diabetes rat model. Diabetes 2008, 57:1664-1673

71. Obrosova IG: Diabetic painful and insensate neuropathy: pathogenesis and potential treatments. Neurotherapeutics 2009, 6:638-647

72. Tilton RG, Chang K, Nyengaard JR, Van den Enden M, Ido $\mathrm{Y}$, Williamson JR: Inhibition of sorbitol dehydrogenase. Effects on vascular and neural dysfunction in streptozocin-induced diabetic rats. Diabetes 1995, 44:234-242

73. Ng TF, Lee FK, Song ZT, Calcutt NA, Lee AY, Chung SS, Chung SK: Effects of sorbitol dehydrogenase deficiency on nerve conduction in experimental diabetic mice. Diabetes 1998, 47:961-966

74. Goss JR, Goins WF, Lacomis D, Mata M, Glorioso JC, Fink DJ: Herpes simplex-mediated gene transfer of nerve growth factor protects against peripheral neuropathy in streptozotocin-induced diabetes in the mouse. Diabetes 2002, 51:2227-2232

75. Calcutt NA, Freshwater JD, Hauptmann N, Taylor EM, Mizisin AP: Protection of sensory function in diabetic rats by Neotrofin. Eur J Pharmacol 2006, 534:187-193

76. Chattopadhyay M, Mata M, Goss J, Wolfe D, Huang S, Glorioso JC, Fink DJ: Prolonged preservation of nerve function in diabetic neuropathy in mice by herpes simplex virus-mediated gene transfer. Diabetologia 2007, 50:1550-1558

77. Schmidt RE, Dorsey DA, Beaudet LN, Parvin CA, Escandon E: Effect of NGF and neurotrophin-3 treatment on experimental diabetic autonomic neuropathy. J Neuropathol Exp Neurol 2001, 60:263-273

78. Hotta N, Toyota T, Matsuoka K, Shigeta Y, Kikkawa R, Kaneko T, Takahashi A, Sugimura K, Koike Y, Ishii J, Sakamoto N: SNK-860 Diabetic Neuropathy Study Group: Clinical efficacy of fidarestat, a novel aldose reductase inhibitor, for diabetic peripheral neuropathy: a 52-week multicenter placebo-controlled double-blind parallel group study. Diabetes Care 2001, 24:1776-1782

79. Casellini CM, Barlow PM, Rice AL, Casey M, Simmons K, Pittenger G, Bastyr EJ 3rd, Wolka AM, Vinik Al: A 6-month, randomized, doublemasked, placebo-controlled study evaluating the effects of the protein kinase C-beta inhibitor ruboxistaurin on skin microvascular blood flow and other measures of diabetic peripheral neuropathy. Diabetes Care 2007, 30:896-902 